\title{
Use of anise seed and/or $\alpha$-tocopheryl acetate in laying Japanese quail diets
}

\author{
E.V. Christaki ${ }^{\#}$, E.M. Bonos \& P.C. Florou-Paneri \\ Laboratory of Animal Nutrition, Faculty of Veterinary Medicine, Aristotle University of Thessaloniki, TK 54124, \\ Thessaloniki, Greece
}

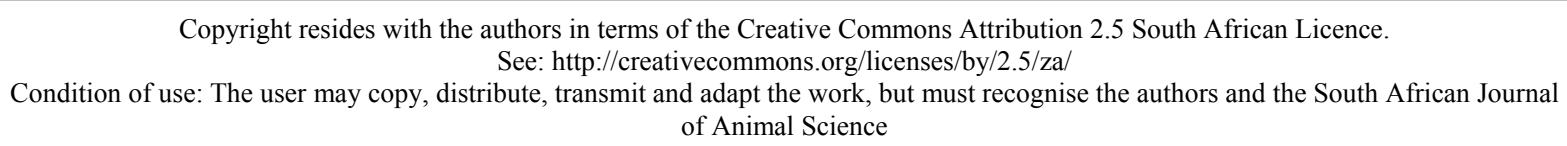

\begin{abstract}
An experiment was conducted to investigate the possible use of anise (Pimpinella anisum) and/or $\alpha$-tocopheryl acetate as dietary supplements on the performance and some egg quality characteristics of laying Japanese quail. One hundred and eight Coturnix japonica quail ( 72 females and 36 males), 149 days old, were randomly allocated to four equal groups with three subgroups of nine birds each (six females and three males). A commercial laying diet was fed to the control group (Group A). The remaining three groups received the same diet supplemented with anise seed at $10 \mathrm{~g} / \mathrm{kg}$ (Group B) or $20 \mathrm{~g} / \mathrm{kg}$ (Group C), or additional $600 \mathrm{mg} \alpha$-tocopheryl acetate/kg (Group D). The birds were given feed and water ad libitum for a period of 29 days, while being kept under commercial conditions. During the experiment, egg production, feed consumption and mortality were recorded daily. Also, at the end of experiment, egg weight, egg yolk, albumen and shell weight percentages, egg yolk colour (using the $\mathrm{L}^{*} \mathrm{a} * \mathrm{~b} *$ colour space), blood serum total cholesterol and triglycerides concentrations were determined. Neither the supplementation of anise nor that of $\alpha$-tocopheryl had any effect on the performance of the birds or the quality of their eggs, except for a significant change of the colour of the egg yolk. Cholesterol concentration in the serum tended to decrease with the addition of anise to the diet.
\end{abstract}

Keywords: Pimpinella anisum, vitamin E, Coturnix japonica, performance, egg characteristics, serum total cholesterol, serum triglycerides

${ }^{\#}$ Corresponding author: efchris@vet.auth.gr

\section{Introduction}

For centuries aromatic plants have been used worldwide as food and for medicinal purposes. Various biological activities, such as antioxidative (Botsoglou et al., 2002; Giannenas et al., 2005; Florou-Paneri et al., 2006), anticoccidial (Christaki et al., 2004; Florou-Paneri et al., 2006) or antimicrobial (Govaris et al., 2007; Botsoglou et al., 2010) properties have been identified in these plants. Consequently, an increasing interest in the use of these products in poultry nutrition has been experienced, especially since the complete ban by the European Union countries in 2006 (EU, 2005) on the use of antibiotics as growth promoters in animals.

Anise (Pimpinella anisum L.), a member of the Apiaceae family, is an annual aromatic plant, native to the eastern Mediterranean and southwestern regions of Asia. The part of the plant used, is the fruit, in particular the seed and its essential oil. Anise seed is listed by the Council of Europe as a natural source of feed flavouring and in the USA it is considered as GRAS, i.e. Generally Recognized As Safe, (Franz et al., 2005; Al-Beitawi et al., 2009).

Anise has been examined for its antiparasitic and digestion stimulating properties (Cabuk et al., 2003), as well as its antibacterial (Tabanca et al., 2003), antifungal (Soliman \& Badea, 2002), antipyretic (Afifi et al., 1994), antioxidant (Gulcin et al., 2003), antimicrobial (Al-Kassie et al., 2008), anthelmintic (Bhatti et al., 1996) and hypocholesterolemic (Craig, 1999) activities. Additionally, anise is reported to possess anticonvulsant (Pourgholam et al., 1999), antiepileptic (Janahmadi et al., 2008) and muscle relaxant (Albuquerque et al., 1995) properties. Some studies have been conducted to evaluate the use of anise seed or 
oil in poultry nutrition, especially to replace antibiotics as growth promoters (Ciftci et al., 2005; Soltan et al., 2008; Al-Beitawi et al., 2009).

It is well documented that dietary vitamin $\mathrm{E}$, in the form of $\alpha$-tocopheryl acetate, is a strong antioxidant in the body; though limited research has been conducted on its potential to improve performance and egg quality traits of laying Japanese quail (Sahin et al., 2006). Antioxidants in poultry diets perform an important role in the good health and performance of poultry and the oxidative stability of their products, and poultry diets are routinely supplemented with antioxidants. Nevertheless, it remains unclear whether the antioxidant properties of aromatic plants are comparable to that of $\alpha$-tocopheryl acetate, which is usually included in commercial poultry diets (Windisch et al., 2008).

The aim of the present study was to investigate the dietary use of anise seeds and $\alpha$-tocopheryl acetate on performance and some egg quality characteristics of laying Japanese quail.

\section{Materials and Methods}

Anise seeds were dried, milled and incorporated into the experimental diet. The chemical analysis of the anise seeds, performed according to the guidelines of AOAC (2005), is presented in Table 1.

Table 1 Chemical analysis of anise seed

\begin{tabular}{lc}
\hline & $\mathrm{g} / \mathrm{kg}$ \\
\hline Dry matter & 935 \\
Crude protein & 129 \\
Crude fat & 138 \\
Crude fibre & 202 \\
Ash & 82 \\
\hline
\end{tabular}

One hundred and eight Coturnix japonica quail (72 females and 36 males), 149 days old, were randomly allocated to four groups with three replications of nine birds each (six females and three males). All the quail were weighed individually at the time of placement in the cages, and average body weights did not differ $(P>0.100)$ between the four treatments. For an acclimatization period of 10 days before the onset of the investigation the birds were fed a commercial layer diet (Table 2) ad libitum. This diet contained 30 $\mathrm{mg} \alpha$-tocopheryl acetate $/ \mathrm{kg}$. After this preliminary period the birds in the control group (Group A) remained on the same basal diet. The birds of the remaining three groups were fed the basal diet supplemented with either ground anise seed at $10 \mathrm{~g} / \mathrm{kg}$ (Group B), or $20 \mathrm{~g} / \mathrm{kg}$ (Group C) or an additional $600 \mathrm{mg} \alpha$-tocopheryl acetate $/ \mathrm{kg}$ feed (Group D). The $\alpha$-tocopheryl acetate used was obtained from Roche Products Ltd. (Hertfordshire, UK). For a period of 29 days the birds received feed and water ad libitum, and were kept under commercial conditions for laying hens. The quail were handled according to the principles of the Greek Directorate General of Veterinary Services for the care of animals in experimentation.

During the experimental period, egg production, feed intake and mortality were recorded daily. At the last day of the experiment, egg weight and egg yolk, albumen and shell (with shell membrane) weight percentages were determined in 10 eggs per replication. Furthermore, egg yolk colour was measured in a mixture of 10 egg yolks from each replication, using the $\mathrm{L}^{*} \mathrm{a}^{*} \mathrm{~b}^{*}$ colour space $(\mathrm{L}=$ lightness, $\mathrm{a}=$ redness, $\mathrm{b}=$ yellowness) according to Herber-McNeill \& Van Elswyk (1998), with the aid of a Konica Minolta Chroma Meter CR-410 (Japan).

At the end of the feeding period, total cholesterol concentration in blood serum was measured according to the method of Roeschlau et al. (1974), and the concentration of blood serum triglycerides was measured according to the method of Fossati \& Prencipe (1982). For both of the above measurements a biochemical analyser, Flexor E, Vital Scientific N.V. (Holland), was used.

The statistical analysis was performed using the SPSS (2007) 16.0.1 statistical package (SPSS Inc., Chigaco, IL, USA). The one-way analysis of variance (ANOVA) for the four groups of the experimentation was performed using the general linear model function of SPSS. Furthermore, regression analysis of the 
effect of the anise was performed using the curve estimation function of SPSS. For the mortality the Pearson's chi square test was used. A value of $P \leq 0.050$ was considered significant and a value of $0.050<P$ $\leq 0.100$ was considered a tendency. Levene's test was applied to test the homogeneity of the variances. The Tukey's test was applied to determine statistical differences between the means.

Table 2 Composition of the basal diet

\begin{tabular}{lllc}
\hline Ingredients & $\mathrm{g} / \mathrm{kg}$ & Chemical composition (analysed) & $\mathrm{g} / \mathrm{kg}$ \\
\hline Maize & 456.7 & Dry matter & 900 \\
Soybean meal & 305.4 & Crude protein & 198 \\
Wheat & 100.0 & Crude fat & 45 \\
Calcium carbonate & 62.1 & Crude fibre & 34 \\
Soybean oil & 30.0 & Ash & 94 \\
Maize gluten meal & 27.7 & & \\
Dicalcium phosphate & 10.4 & Calculated analysis \\
Vitamin and trace mineral premix ${ }^{1}$ & 3.5 & Calcium & 26 \\
Salt & 2.1 & Total phosphorus & 6 \\
Sodium bicarbonate & 1.9 & Lysine & 10.2 \\
Methionine & 0.2 & Methionine \& cystine & 7.2 \\
& & Metabolisable energy, MJ/kg & 12.13
\end{tabular}

${ }^{1}$ Supplying per kg feed: $14000 \mathrm{IU}$ vitamin $\mathrm{A} ; 5000 \mathrm{IU}$ vitamin $\mathrm{D}_{3} ; 30 \mathrm{mg}$ vitamin E; $13 \mathrm{mg}$ vitamin $\mathrm{K} ; 3 \mathrm{mg}$ vitamin $\mathrm{B}_{1} ; 8 \mathrm{mg}$ vitamin $\mathrm{B}_{2} ; 3 \mathrm{mg}$ vitamin $\mathrm{B}_{6} ; 20 \mu \mathrm{g}$ vitamin $\mathrm{B}_{12} ; 85 \mathrm{mg}$ vitamin niacin; $20 \mathrm{mg}$ pantothenic acid; $2 \mathrm{mg}$ folic acid; $200 \mu \mathrm{g}$ biotin; $10 \mathrm{mg}$ vitamin C; $960 \mathrm{mg}$ choline chloride; $100 \mathrm{mg} \mathrm{Zn;} 116 \mathrm{mg}$ Fe; 120 $\mathrm{mg} \mathrm{Mg} ; 20 \mathrm{mg} \mathrm{Cu} ; 0.2 \mathrm{mg} \mathrm{Co} ; 1 \mathrm{mg} \mathrm{I} ; 0.3 \mathrm{mg} \mathrm{Se}$.

\section{Results}

At the completion of the trial, feed intake and mortality did not differ $(P>0.100)$ between the groups (Table 3). Similarly, the regression analysis of the effect of anise on the performance parameters (Table 6) showed no $(P>0.100)$ differences.

Table 3 Performance of laying quail (mean \pm SD)

\begin{tabular}{cccc}
\hline Group & $\begin{array}{c}\text { Egg production } \\
\%\end{array}$ & $\begin{array}{c}\text { Daily feed intake } \\
\mathrm{g}\end{array}$ & $\begin{array}{c}\text { Mortality } \\
\%\end{array}$ \\
\hline $\mathrm{A}$ & $70.9 \pm 11.51$ & $32.3 \pm 4.3$ & 0 \\
$\mathrm{~B}$ & $73.4 \pm 13.32$ & $28.6 \pm 4.0$ & $3.7 \pm 6.4$ \\
$\mathrm{C}$ & $76.3 \pm 3.17$ & $29.3 \pm 0.5$ & 0 \\
$\mathrm{D}$ & $59.4 \pm 10.54$ & $31.5 \pm 0.5$ & 0 \\
$P$ value & 0.282 & 0.419 & 0.387
\end{tabular}

Groups: $\mathrm{A}=$ control; $\mathrm{B}=10 \mathrm{~g}$ anise $/ \mathrm{kg} ; \mathrm{C}=20 \mathrm{~g}$ anise $/ \mathrm{kg} ; \mathrm{D}=600 \mathrm{mg}$ vitamin $\mathrm{E} / \mathrm{kg}$. Column means did not differ significantly at $P \leq 0.050$.

The results concerning the effect of the dietary addition of anise and $\alpha$-tocopheryl acetate on some egg quality parameters are presented in Table 4. Egg weight (g), yolk, albumen and shell weight (\%) did not 
differ $(P>0.100)$ between the treatment groups. The egg yolk colour was affected $(P \leq 0.001)$ since the eggs of group D had a lower $\mathrm{L}^{*}$ parameter value compared to those of groups B and C. Also, the eggs of group D had a higher $\mathrm{a}^{*}$ parameter value compared to those of groups $\mathrm{A}, \mathrm{B}$ and $\mathrm{C}$, whereas no difference $(P>0.100)$ between treatments was found in the $\mathrm{b}^{*}$ parameter. Furthermore, regression analysis of the effect of anise (Table 6) showed a tendency $(P \leq 0.100)$ for a linear increase of the $\mathrm{L}^{*}$ parameter with $\mathrm{R}^{2}=0.349$ and also a linear increase $(P \leq 0.050)$ of the $\mathrm{b}^{*}$ parameter with $\mathrm{R}^{2}=0.484$.

Table 4 Egg quality parameters (mean \pm SD)

\begin{tabular}{cccccccc}
\hline \multirow{2}{*}{ Group } & Egg weight & Egg yolk & Egg albumen & Egg shell & \multicolumn{3}{c}{ Yolk colour } \\
\cline { 6 - 8 } & $\mathrm{g}$ & $\%$ & $\%$ & $\%$ & $\mathrm{~L}^{*}$ & $\mathrm{a}^{*}$ & $\mathrm{~b}^{*}$ \\
\hline & & & & & & & \\
$\mathrm{A}$ & $11.95 \pm 0.02$ & $31.39 \pm 0.48$ & $54.10 \pm 1.41$ & $14.52 \pm 0.99$ & $68.80^{\mathrm{ab}} \pm 0.41$ & $2.16^{\mathrm{a}} \pm 0.74$ & $64.13 \pm 0.35$ \\
$\mathrm{~B}$ & $11.63 \pm 0.26$ & $32.59 \pm 0.85$ & $53.04 \pm 0.82$ & $14.38 \pm 0.19$ & $70.19^{\mathrm{a}} \pm 0.31$ & $1.85^{\mathrm{a}} \pm 0.65$ & $65.85 \pm 1.01$ \\
$\mathrm{C}$ & $11.82 \pm 0.04$ & $32.01 \pm 0.95$ & $54.07 \pm 1.62$ & $13.92 \pm 0.79$ & $69.97^{\mathrm{a}} \pm 0.90$ & $2.37^{\mathrm{a}} \pm 0.13$ & $66.25 \pm 1.42$ \\
$\mathrm{D}$ & $11.84 \pm 0.2$ & $32.27 \pm 1.14$ & $53.73 \pm 2.68$ & $14.00 \pm 1.80$ & $67.65^{\mathrm{b}} \pm 0.58$ & $3.72^{\mathrm{b}} \pm 0.10$ & $65.11 \pm 0.72$ \\
$P$ value & 0.263 & 0.444 & 0.869 & 0.888 & 0.003 & 0.008 & 0.106 \\
& & & & & &
\end{tabular}

Groups: $\mathrm{A}=$ control; $\mathrm{B}=10 \mathrm{~g}$ anise $/ \mathrm{kg} ; \mathrm{C}=20 \mathrm{~g}$ anise $/ \mathrm{kg} ; \mathrm{D}=600 \mathrm{mg}$ vitamin $\mathrm{E} / \mathrm{kg}$.

Column means with different superscripts differ significantly at $P \leq 0.010$.

Table 5 presents the effect of the dietary addition of anise and $\alpha$-tocopheryl acetate on blood serum total cholesterol and triglyceride concentrations. Total cholesterol values had a tendency $(P \leq 0.100)$ to be lower for the quail in group B compared to those in groups A and D, while triglycerides values did not differ $(P>0.100)$ between treatments. In addition, regression analysis of the effect of the anise on the above parameters (Table 6$)$ showed a tendency $(P \leq 0.100)$ for a linear decrease of total cholesterol concentration with $\mathrm{R}^{2}=0.406$.

Table 5 Blood serum total cholesterol and triglycerides (mean \pm SD) concentrations

\begin{tabular}{ccc}
\hline Group & $\begin{array}{c}\text { Total cholesterol } \\
\mathrm{mg} / \mathrm{dL}\end{array}$ & $\begin{array}{c}\text { Triglycerides } \\
\mathrm{mg} / \mathrm{dL}\end{array}$ \\
\hline $\mathrm{A}$ & $204.7^{\mathrm{a}} \pm 35.5$ & $257.0 \pm 74.8$ \\
$\mathrm{~B}$ & $156.7^{\mathrm{b}} \pm 8.5$ & $131.0 \pm 17.3$ \\
$\mathrm{C}$ & $160.0^{\mathrm{ab}} \pm 14.1$ & $213.3 \pm 94.5$ \\
$\mathrm{D}$ & $204.3^{\mathrm{a}} \pm 32.0$ & $259.3 \pm 116.2$ \\
$P$ value & 0.077 & 0.282 \\
\hline
\end{tabular}

Groups: $\mathrm{A}=$ control; $\mathrm{B}=10 \mathrm{~g}$ anise $/ \mathrm{kg} ; \mathrm{C}=20 \mathrm{~g}$ anise $/ \mathrm{kg}$; $\mathrm{D}=600 \mathrm{mg}$ vitamin $\mathrm{E} / \mathrm{kg}$. Column means with different superscripts differ significantly at $P \leq 0.100$.

\section{Discussion}

The objective of this study was to investigate the use of anise as a feed additive in laying Japanese quail nutrition. According to Franz et al. (2005), anise seeds contain 2 - 6\% essential oil and also phenolic acids, flavonol and flavone glycosides. The predominant constituent of the essential oil is trans-anethole (80 - 95\% of total oil), a powerful flavouring which belongs to the phytoestrogens (Albert-Puleo, 1980). 
Table 6 Regression analysis of the effect of dietary anise on laying percentage and egg quality parameters

\begin{tabular}{lccl}
\hline Parameter & $P$ & $\mathrm{R}^{2}$ & Linear regression equations \\
\hline Egg production, \% & 0.514 & 0.063 & $=70.822+0.268 \times$ Anise $(\mathrm{g} / \mathrm{kg})$ \\
Daily feed intake, g & 0.317 & 0.142 & $=31.510-0.148 \times$ Anise $(\mathrm{g} / \mathrm{kg})$ \\
Egg weight, g & 0.457 & 0.081 & $=11.866-0.006 \times$ Anise $(\mathrm{g} / \mathrm{kg})$ \\
Egg yolk, \% & 0.408 & 0.100 & $=31.684+0.031 \times$ Anise $(\mathrm{g} / \mathrm{kg})$ \\
Egg albumen, \% & 0.984 & 0.000 & $=553.747-0.001 \times$ Anise $(\mathrm{g} / \mathrm{kg})$ \\
Egg shell, \% & 0.321 & 0.140 & $=14.570-0.030 \times$ Anise $(\mathrm{g} / \mathrm{kg})$ \\
Yolk colour, L* & 0.094 & 0.349 & $=69.135+0.055 \times$ Anise $(\mathrm{g} / \mathrm{kg})$ \\
Yolk colour, a* & 0.664 & 0.029 & $=2.020+0.011 \times$ Anise $(\mathrm{g} / \mathrm{kg})$ \\
Yolk colour, b* & 0.037 & 0.484 & $=64.354+0.106 \times$ Anise $(\mathrm{g} / \mathrm{kg})$ \\
Total cholesterol, mg/dL & 0.065 & 0.406 & $=196.111-2.233 \times$ Anise $(\mathrm{g} / \mathrm{kg})$ \\
Triglycerides, mg/dL & 0.552 & 0.053 & $=222.278-2.183 \times$ Anise $(\mathrm{g} / \mathrm{kg})$ \\
\hline
\end{tabular}

Moreover, small amounts of eugenol, estragole, methyl-chavicol, anisaldehyde, $\beta$-caryophilline, anise ketone (methyloxyphenylacetone) and the polymers of anethole are present in the oil (Ciftci et al., 2005; Franz et al., 2005; Al-Beitawi et al., 2009).

In the present study, quail egg production was not significantly affected by the dietary incorporation of anise seed, a result in line with those of Bayram et al. (2007). However, El-Deeb et al. (2007) reported that feeding anise to quail decreased egg laying rate by $10.3 \%$. In laying hens, Ali et al. (2007) recorded higher egg production when anise was supplemented to their diet. Moreover, in the present experiment daily feed intake did not differ significantly between the four groups. Bayram et al. (2007) noted an increase of feed intake of laying Japanese quail due to the addition of anise seeds to the diet. Mortality was not significantly affected over the total feeding period, a finding which is in agreement with that of Al-Beitawi et al. (2009) who fed anise seed to broilers. The lack of an effect on performance may be explained by the excellent hygienic condition in the present experiment, since it cannot be excluded that beneficial effects of feed additives might be more evident under less hygienic housing conditions and/or when using less digestible diets (Bonos et al., 2010).

The supplementation of the quail diet with $\alpha$-tocopheryl acetate at $600 \mathrm{mg} / \mathrm{kg}$ feed had no adverse influence on feed intake, mortality and egg production compared to the control group where the diet contained $30 \mathrm{mg} \alpha$-tocopheryl acetate $/ \mathrm{kg}$ feed. In a previous study, Sahin et al. (2006) observed that the dietary addition of $\alpha$-tocopheryl acetate to quail diets increased egg production, but did not affect feed intake. Kucuk et al. (2003) and Biswas et al. (2010) reported increased egg production in laying hens, whereas Heydari et al. (2009) did not observe any improvement in laying performance.

Egg weight, yolk, albumen and shell percentage were not significantly affected by the dietary addition of either anise seed or $\alpha$-tocopheryl acetate in the present study. In a previous study, Bayram et al. (2007) reported that egg weight was reduced when quail were fed anise seeds at inclusion levels of 3\% and 5\%. Other researchers (Ali et al., 2007) noticed that egg weight and yolk, albumen and shell weight were not influenced when anise was fed to laying hens. Biswas et al. (2010) did not find any significant difference in egg weight, yolk and albumen percentage in laying hens fed added vitamin E.

The egg yolk colour, parameter a* (redness), was significantly increased by the dietary addition of $\alpha$-tocopheryl acetate, but anise seed did not modify the $\mathrm{L}^{*}, \mathrm{a}^{*}$ and $\mathrm{b}^{*}$ colour parameters. Ali et al. (2007) did not record significant differences in egg yolk colour of hens fed anise seed. Similarly, Grobas et al. (2002) found no difference in egg yolk colour of hens that consumed increasing quantities of vitamin $\mathrm{E}$.

The results of the present experiment showed that serum total cholesterol concentration was significantly reduced when anise seed were incorporated in the quail diet, a finding that agrees with those of Ali et al. (2007) in laying hens. In contrast, Soltan et al. (2006) found that anise seed in broiler diets did not affect serum total cholesterol concentration. The cholesterol reducing effect may be attributed mainly to the effect of the trans-anethole. According to researchers (Knight \& Eden, 1996; Yildiz, 2005) phytoestrogen 
consumption can regulate serum cholesterol levels in the human and animals. Moreover, in this study serum triglyceride concentrations were not affected by anise seeds or $\alpha$-tocopheryl acetate. Ali et al. (2007) found that dietary anise decreased the levels of serum triglycerides and total lipids. Also, Arslan et al. (2001) did not record significant differences in plasma cholesterol and triglycerides levels when vitamin E levels were increased in the diets of broilers. Nevertheless, Francini et al. (1988) reported that the supplementation of vitamin E decreased cholesterol and triglyceride levels in broilers, though this effect was influenced by the age of the birds.

\section{Conclusion}

In conclusion, the incorporation of anise seeds in the feed of laying Japanese quail modified egg yolk colour and had a cholesterol lowering effect in blood serum, without having any adverse effect on performance and the other egg quality characteristics.

\section{References}

Afifi, N.A., Ramadan, A., El-Kashoury, E.A. \& El-Banna, H.A., 1994. Some pharmacological activities of essential oils of certain umbelliferous fruits. Vet. Med. J. Giza 42, 85-92.

Al-Beitawi, N.A., El-Ghousein, S.S. \& Abdullah, H.N., 2009. Antibiotic growth promoters and anise seeds in broiler diets. Jordan J. Agric. Sci. 5, 472-481.

Albert-Puleo, M., 1980. Fennel and anise as estrogenic agents. J. Ethnopharmacology 2, 337-44.

Albuquerque, A.A., Sorenson, A.L. \& Leal-Cardoso, J.H., 1995. Effects of essential oil of Croton zehntneri and of anethole and estragole on skeletal muscles. J. Ethnopharmacology 49, 41-49.

Ali, M.N., Hassan, M.S. \& Abd El-Ghany, F.A., 2007. Effect of strain, type of natural antioxidant and sulphate ion on productive, physiological and hatching performance of native laying hens. Int. J. Poult. Sci. 6, 539-554.

Al-Kassie, G.A.M., 2008. The effect of anise and rosemary on broiler performance. Int. J. Poult. Sci. 7, 243-245.

AOAC, 2005. Official Methods of Analysis. (18th ed.). Ed. Horwitz, W., Association of Analytical Chemists, AOAC International, Arlington, Virginia, USA.

Arslan, M., Ozcan, M., Matur, E., Coterlioglou, U. \& Ergul, E., 2000. The effects of vitamin E on some blood parameters in broilers. Turk. J. Vet. Anim. Sci. 25, 711-716.

Bayram, I., Sadi Cetingul, I., Akkaya, B. \& Uyarlar, C., 2007. Effect of aniseed (Pimpinella anisum L.) on egg production, quality, cholesterol levels, hatching results and the antibody values in blood of laying quails (Coturnix coturnix japonica). Archiva Zootechnica 10, 73-77.

Bhatti, M.A., Khan, M.T.J., Ahmed, B., Jamshaid, M. \& Ahmad, W., 1996. Antibacterial activity of aniseed (Pimpinella anisum). Fitoterapia 67, 372-374.

Biswas, A., Mohan, J. \& Sastry, K.V.H., 2010. Effect of vitamin E on production performance and egg quality traits in Indian Native Kadaknath hen. Asian-Aust. J. Anim. Sci. 23, 396-400.

Bonos, E., Christaki, E. \& Florou-Paneri, P., 2010. Effect of dietary supplementation of mannan oligosaccharides and acidifier calcium formate on the performance and carcass quality of Japanese quail (Coturnix japonica). J. Food Agric. Environ. 8, 611-617.

Botsoglou, N.A., Christaki, E., Fletouris, D.J., Florou-Paneri, P. \& Spais, A.B., 2002. The effect of dietary oregano essential oil on lipid oxidation in raw and cooked chicken during refrigerated storage. Meat Sci. 62, 259-265.

Botsoglou, E., Govaris, A., Christaki, E. \& Botsoglou, N., 2010. Effect of dietary olive leaves and/or $\alpha$-tocopheryl acetate supplementation on microbial growth and lipid oxidation of turkey breast fillets during refrigerated storage. Food Chem. 121, 17-22.

Cabuk, M., Alcicek, A., Bozkurt, M. \& Imre, N., 2003. Antimicrobial properties of the essential oils isolated from aromatic plants and using possibility as alternative feed additives. II National Animal Nutrition Congress, 18-20 September. pp. 184-187.

Christaki, E., Florou-Paneri, P., Giannenas, I., Papazahariadou, M., Botsoglou, N.A. \& Spais, A.B., 2004. Effect of a mixture of herbal extracts on broiler chickens infected with Eimeria tenella. Anim. Res. 53, 137-144.

Ciftci, M., Guler, T., Dalkilic, B. \& Nihat Ertas, O., 2005. The effect of anise oil (Pimpinella anisum L.) on broiler performance. Int. J. Poult. Sci. 4, 851-855. 
Craig, W.J., 1999. Health-promoting properties of common herbs. Am. J. Chin. Nutr. 70 (Suppl.), 491-499.

El-Deeb, M.A., Metwally, M.A. \& Galal, A.E., 2007. The impact of botanical extract, capsicum (Capsicum frutescence L.), anise and molukhyia (Corchorus olitorius) supplementation and their interactions on productive and reproductive performance of Japanese quail (Coturnix japonica). $4^{\text {th }}$ World Poultry Conference, 27-30 March, 2007, Sharm El-Seikh, Egypt. pp. 455-464.

EU, 2005. Ban on antibiotics as growth promoters in animal feed enters into effect. IP/05/1687, 22/December/2005. European Union. http:// europa.eu/ rapid/ pressReleasesAction.do? reference $=\mathrm{IP} / 05 / 1687 \quad \&$ format $=\mathrm{HTML} \quad$ \&aged $=0 \quad$ \&language $=\mathrm{EN} \quad$ \&guiLanguage $=$ en $\quad$ accessed January 2010].

Florou-Paneri, P., Christaki, E., Giannenas, I., Papazahariadou, M., Botsoglou, N.A. \& Spais, A.B., 2004. Effect of dietary olympus tea (Sideritis scardica) supplementation on performance of chickens challenged with Eimeria tenella. J. Anim. Feed Sci. 13, 303-313.

Florou-Paneri, P., Giannenas, I., Christaki, E., Govaris, A. \& Botsoglou, N., 2006. Performance of chickens and oxidative stability of the produced meat as affected by feed supplementation with oregano, vitamin C, vitamin E and their combinations. Arch. Geflugelk. 70, 232-240.

Fossati, P. \& Prencipe, L., 1982. Serum triglycerides determined colorimetrically with an enzyme that produces hydrogen peroxide. Clin. Chem. 28, 2077-2080.

Francini, A., Meluzzi, A., Bertuzzi, S. \& Giordani, G., 1988. High doses of vitamin E in the broilers diets. Arch. Geflugelk. 52, 12-16.

Franz, C., Bauer, R., Carle, R., Tedesco, D., Tubaro, A. \& Zitteri-Eglseer, K., 2005. Study of the assessment of plants/herb extracts and their naturally or synthetically produced components as "additives" for use in animal production. CFT/EFSA/FEEDAP/2005/01.

Giannenas, I.A., Florou-Paneri, P., Botsoglou, N.A., Christaki, E. \& Spais, A.B., 2005. Effect of supplementing feed with oregano and/or $\alpha$-tocopheryl acetate on growth of broiler chickens and oxidative stability of meat. J. Anim. Feed Sci. 14, 521-535.

Govaris, A., Florou-Paneri, P., Botsoglou, E., Giannenas, I., Amvrosiadis, I. \& Botsoglou, N., 2007. The inhibitory potential of feed supplementation with rosemary and/or $\alpha$-tocopheryl acetate on microbial growth and lipid oxidation of turkey breast during refrigerated storage. LWT--Food Sci. Technol. 40, 331-337.

Grobas, S., Mendez, J., Lopez Bote, C., De Blas, C. \& Mateos, G.G., 2002. Effect of vitamin E and A supplementation on egg yolk $\alpha$-tocopherol concentration. Poult. Sci. 81, 376-381.

Gulcin, I., Oktay, M., Kirecci, E. \& Irfan Kufrevioglu, O., 2003. Screening of antioxidant and antimicrobial activities of anise (Pimpinella anisum L.) seed extract. Food Chem. 83, 371-382.

Herber-McNeill, S.M. \& Van Elswyk, M.E., 1998. Dietary marine algae maintains egg consumer acceptability while enhancing yolk colour. Poult. Sci. 77, 493-496.

Heydari, A., Eslami, H., Roshanfekr, H., Bojarpur, M. \& Ghorbani, M.R., 2009. Effects of different levels of processed fat and vitamin E on laying hens performance and egg yolk cholesterol. Res. J. Agric. Biol. Sci. 4, 1162-1164.

Janahmadi, M., Farajnia, S., Vatanparast, J., Abbasipour, H. \& Kamalinejad, M., 2008. The fruit essential oil of Pimpinella anisum L. (Umbelliferae) induces neuronal hyperexcitability in snail partly through attenuation of after-hyperpolarization. J. Ethnopharmacol. 120, 360-365.

Knight, D.C. \& Edens, J.A., 1996. A review of the clinical effects of phytoestrogens. Obstet. Gynecol. 87, 897-904.

Kucuk, O., Sahin, N., Sahin, K., Gursu, M.F., Gulcu, F., Ozcelic, M. \& Issi, M., 2003. Egg production, egg quality, and lipid peroxidation status in laying hens maintained at a low ambient temperature $\left(6^{\circ} \mathrm{C}\right)$ and fed a vitamin C and vitamin E-supplemented diet. Vet. Med. (Prague, Czech Repub.) 48, 33-40.

Pourgholam, M.H., Majzoob, S., Javadi, M., Kamalinejad, M., Fanaee, G.H. \& Sayyah, M., 1999. The fruit essential oil of Pimpinella anisum exerts anticonvulsant effect in mice. J. Ethnopharmacol. 66, 211-215.

Roeschlau, P., Bernt, E. \& Gruber, W., 1974. Enzymatic determination of total cholesterol in serum. J. Clin. Chem. Clin. Biochem. 12, 403-407.

Sahin, N., Sahin, K., Onderci, M., Karatepe, M., Smith, M.O. \& Kucuk, O., 2006. Effects of dietary lycopene and vitamin $\mathrm{E}$ on egg production, antioxidant status and cholesterol levels in Japanese quail. Asian-Aust. J. Anim. Sci. 19, 224-230. 
Soliman, K.M. \& Badea, R.I., 2002. Effect of oil extracted from some medicinal plants on different mycotoxigenic fungi. Food Chem. Toxicol. 40, 1669-1675.

Soltan, M.A., Shewita, R.S. \& El-Katcha, M.I., 2008. Effect of dietary anise seeds supplementation on growth performance, immune response, carcass traits and some blood parameters of broiler chickens. Int. J. Poult. Sci. 7, 1078-1088.

SPSS, 2007. SPSS 16.0.1 for Windows. SPSS Inc., Chicago, IL, USA. http://www.spss.com [accessed January 2010].

Tabanca, N., Bedir, E., Kirimer, N., Baser, K.H., Khan, S.I., Jacob, M.R. \& Khan, I.A., 2003. Antimicrobial compounds from Pimpinella species growing in Turkey. Planta Medical 69, 933-938.

Windisch, W., Schedle, K., Plitzner, C. \& Kroismayr, A., 2008. Use of phytogenic products as feed additives for swine and poultry. J. Anim. Sci. 86, E140-148.

Yildiz, F., 2005. Phytoestrogens in Functional Foods. Taylor \& Francis Ltd. USA. pp. 3-5. 